\title{
Are thermophilic microorganisms active in cold environments?
}

\author{
Charles S. Cockell, Claire Cousins, Paul T. Wilkinson, Karen Olsson- \\ Francis, Ben Rozitis
}

\begin{abstract}
The mean air temperature of the Icelandic interior is below $10^{\circ} \mathrm{C}$. However, we have previously observed 165 rDNA sequences associated with thermophilic lineages in Icelandic basalts. Measurements of the temperatures of igneous rocks in Iceland showed that solar insolation of these low albedo substrates achieved a peak surface temperature of $44.5^{\circ} \mathrm{C}$. We isolated seven thermophilic Geobacillus species from basalt with optimal growth temperatures of $\sim 65^{\circ} \mathrm{C}$. The minimum growth temperature of these organisms was $\sim 36^{\circ} \mathrm{C}$, suggesting that they could be active in the rock environment. Basalt dissolution rates at $40^{\circ} \mathrm{C}$ were increased in the presence of one of the isolates compared to abiotic controls, showing its potential to be involved in active biogeochemistry at environmental temperatures. These data raise the possibility of transient active thermophilic growth in macroclimatically cold rocky environments, implying that the biogeographical distribution of active thermophiles might be greater than previously understood. These data show that temperatures measured or predicted over large scales on a planet are not in themselves adequate to assess niches available to extremophiles at micron scales.
\end{abstract}

\section{Introduction}

Iceland is a sub-Arctic volcanic island formed by on-going volcanic eruptions of a localised mantle plume and mid-Atlantic rift volcanism (Lawver \& Muller 1994). Consequently, the majority of the island consists of basaltic lithologies with poorly developed andisols (Arnalds 2004). The high latitude of the island and an elevated inland plateau causes the mean inland annual air temperature to be $<10^{\circ} \mathrm{C}$ (Einarsson 1984; Striberger et al. 2010). The inland basalts have a typical organic carbon content of $<0.15 \%$ (Kelly et al. 2011), comparable to regions of the Atacama Desert (Barros et al. 2008). The interaction of ice and volcanism has made Iceland a focus in Mars analogue studies (Cousins \& Crawford 2010).

Despite the inhospitable environmental conditions, the island hosts diverse microbiological populations. Icelandic basaltic and rhyolitic glass and minerals host a variety of bacterial taxa (Herrera et al. 2008; Cockell et al. 2009; Kelly et al. 2010, 2011). The microbial communities of volcanic rocks are typically dominated by Acidobacteria, Cyanobacteria and Actinobacteria (Cockell et al.2009; Kelly et al. 2010, 2011).

However, microbial species atypical of this environment have also been detected. Potentially thermophilic taxa such as Geobacillus and Thermobacterium have been identified via microarray analysis (G2 PhyloChip) of the 16S rDNA gene amplified from the whole rock community genomic DNA (Kelly et al. 2010, 2011), despite the fact that the atmospheric temperature of Iceland does not approach the range required for thermophile activity. 
However, rock temperatures can exceed air temperatures. In Antarctic sandstones, for instance, temperatures have been observed to be $10-15^{\circ} \mathrm{C}$ higher than local atmospheric temperature (McKay \& Friedmann 1985; Hall et al. 2005). Icelandic basalts have a low albedo of approximately 0.11 , suggesting they will absorb solar radiation (McGreevy 1985) and potentially exhibit surface and near-surface temperatures higher than air temperatures.

In this paper, we sought to address the hypothesis that Icelandic rocks could reach a sufficient temperature to support the activity of thermophilic organisms despite the fact that the macroclimatic conditions have a mean annual temperature well below the optimum temperature for thermophiles.

\section{Methods}

\section{Temperatures of basalt}

A sample of vesicular basalt of size approximately $20 \times 30 \times 20 \mathrm{~cm}$ was collected from a lava flow at $64^{\circ} 4.83^{\prime} \mathrm{N}, 19^{\circ} 32.53 \mathrm{~W}$ approximately $4 \mathrm{~km}$ north of Lanmannalaugur, Iceland. Holes were drilled into the rock from the sides at $2 \mathrm{~cm}$ depth from the surface, and the rock was returned to the field site. This depth was chosen to probe the endolithic habitat near the surface of the rock where water and potentially carbon from phototrophs are available. Thermistors (TMC20-HD), connected to temperature logging probes (HOBO U12 4 external dataloggers, Onset Computing, Pocasset, MA, USA), were inserted into the rock holes at $2 \mathrm{~cm}$ depth. The temperature in the basalt was measured from 4 July 2009 to 27 June 2010 every hour. At the same intervals a separate thermistor was used to measure air temperature $10 \mathrm{~cm}$ above the rock.

Similar measurements were made in an outcrop of obsidian. Obsidian is a silicarich volcanic glass which is resistant to weathering and oxidation causing it to have a dark, almost black colouration (Herrera et al. 2009), giving it one of the lowest albedos of igneous habitats. Measurements at $2 \mathrm{~cm}$ depth in the outcrop $\left(64^{\circ} 2.01^{\prime} \mathrm{N}\right.$, $19^{\circ} 7.75 \mathrm{~W}$ ) were obtained from 9 June 2007 to 11 June 2008.

From 1 June 2007 to 30 June 2008 relative humidity was measured at the obsidian outcrop using a HOBO U23 Relative Humidity data logger (Onset Computing, Pocasset, MA, USA) at 30 min intervals.

During June 2008, a period of warm weather prompted us to measure temperatures in more detail in the obsidian outcrop. Measurements were taken at the surface of the outcrop every 5 min during five consecutive days (11-16 June 2008).

\section{Samples used to isolate thermophiles}

Vesicular basalt (designated here, VBas1) was aseptically collected in June 2008 from the same lava flow at which temperatures were measured. The flow was produced approximately 80-800 thousand years ago (Crovisier et al. 2003). Basaltic tephra produced from the April 2010 eruption of the Eyjafjallajökull at $63^{\circ} 38.22{ }^{\prime} \mathrm{N}, 19^{\circ} 26.97 \mathrm{~W}$ was also collected into aseptic bags (Whirlpak, Fisher Scientific, Loughborough, UK) approximately 14 weeks after the eruption. Samples were maintained at ambient temperatures. X-ray florescence spectrometry (XRF, Applied Research Laboratories 8420 + dual goniometer, Thermo Scientific, Waltham, MA, USA) was used to characterise major elements present in the basalt sample. Heavy metal concentrations 
were measured by inductively coupled plasma mass spectrometry (ICP-MS, Agilent 7500 s, Berkshire, UK).

\section{Culture and isolation of thermophilic organisms}

Thermophilic organisms were isolated using complex organic media incubated at temperatures above $50{ }^{\circ} \mathrm{C}$. Thermophilic enrichments were prepared using tryptone soya broth (TSB) (Oxoid, Basingstoke, UK) produced to manufacturer's instructions. Solid medium was produced with the addition of $3 \% \mathrm{wt} / \mathrm{vol}$. agar (Oxoid Agar No. 1, Basingstoke, UK). Media was adjusted to $\mathrm{pH} 7.4$ with phosphate buffer and then autoclaved $\left(20 \mathrm{~min}\right.$ at $\left.121^{\circ} \mathrm{C}\right)$. For microbial enrichments, $50 \mathrm{ml}$ of TSB was inoculated with $1 \mathrm{~g}$ of crushed sample (approximate grain size $1 \mathrm{~mm}$ ) and then incubated at $50{ }^{\circ} \mathrm{C}$ with three further identical inoculations incubated at $70{ }^{\circ} \mathrm{C}$. This was performed to prevent heat damage to initially dormant cells (Beaman et al. 1988). To isolate thermophiles, enrichments were streaked onto TSB agar plates and incubated at $70{ }^{\circ} \mathrm{C}$ repeatedly until single isolates were obtained. Isolates were stored in 10 wt. $\%$ glycerol at $-80{ }^{\circ} \mathrm{C}$.

\section{Minimum and optimum growth conditions of isolates}

The minimum and optimum growth temperature range was determined for isolates in order to assess the potential activity of organisms in the natural environment. Specific growth rates were measured over the temperature range of $30-90^{\circ} \mathrm{C}$ using two degree increments at temperatures lower than $40^{\circ} \mathrm{C}$ and $10^{\circ} \mathrm{C}$ increments at higher temperatures. Isolates were revived by gradually increasing the incubation temperatures to avoid heat shocking the cells (Beaman et al. 1988). For growth analysis, $500 \mu \mathrm{l}$ of mid-log phase culture (grown at $60^{\circ} \mathrm{C}$ ) was inoculated into $50 \mathrm{ml}$ of pre-warmed TSB media which was incubated at the required temperature in a rotary incubator. To monitor growth, $1 \mathrm{ml}$ of culture was aseptically removed as required and the optical density at $650 \mathrm{~nm}$ was measured with a Helios spectrophotometer (Thermo Scientific, Cambridge, UK).

At temperatures below $40^{\circ} \mathrm{C}$, inhibitors in complex media are thought to limit thermophilic growth (Claes 1968). Therefore, at temperatures below $40^{\circ} \mathrm{C}$, growth analysis was carried out in a defined minimal salts medium (MSM) containing $1 \mathrm{mM}$ of glucose as a carbon source. MSM consisted of, per litre, $0.04 \mathrm{~g} \mathrm{~K}_{2} \mathrm{HPO}_{4}, 0.075 \mathrm{~g}$ $\mathrm{MgSO}_{4} \cdot 7 \mathrm{H}_{2} \mathrm{O}, 0.036 \mathrm{~g} \mathrm{CaCl}_{2} \cdot 2 \mathrm{H}_{2} \mathrm{O}, 0.02 \mathrm{~g} \mathrm{Na}_{2} \mathrm{CO}_{3}, 0.05 \mathrm{~g}$ EDTA and $1 \mathrm{ml} \mathrm{l}^{-1}$ of A5 trace metal solution (containing, per litre, $2.86 \mathrm{~g} \mathrm{H}_{3} \mathrm{BO}_{3}, 1.81 \mathrm{~g} \mathrm{MnCl}_{2} \cdot 4 \mathrm{H}_{2} \mathrm{O}, 0.22 \mathrm{~g}$ $\left.\mathrm{ZnSO}_{4} \cdot 7 \mathrm{H}_{2} \mathrm{O}, 0.39 \mathrm{~g} \mathrm{Na}_{2} \mathrm{MoO}_{4} \cdot 2 \mathrm{H}_{2} \mathrm{O}, 0.08 \mathrm{~g} \mathrm{CuSO}_{4} \cdot 5 \mathrm{H}_{2} \mathrm{O}, 0.05 \mathrm{~g} \mathrm{Co}\left(\mathrm{NO}_{3}\right)_{2} \cdot 6 \mathrm{H}_{2} \mathrm{O}\right)$.

Growth at low temperatures was monitored by cell counts since optical density measurements did not give reliable results. One millilitre of culture was filtered through a $0.2 \mu \mathrm{m}$ polycarbonate filter disc (Whatman, Fisher Scientific, Cambridge, UK) using a vacuum pump. Cells were stained with SYBR Green (Invitrogen, Paisley, UK) according to the manufacturer's instructions and observed under a UV fluorescence microscope (Lecia, DMRP, Wetzlar, Germany). Stained cells were observed using an excitation waveband of 450-490 nm (Leica filter cube I3) and an emission long band cut-off filter of $>515 \mathrm{~nm}$. Counts were performed for 50 random fields of view with cell numbers being calculated per $\mathrm{ml}$ of media.

In order to determine whether autochthonous nutrients can support thermophilic growth, $50 \mathrm{ml}$ of MSM was supplemented with $1 \mathrm{~g}$ of sterile (autoclaved) powdered 
basalt sample as the sole organic nutrient source. This medium was inoculated with $500 \mu \mathrm{l}$ of thermophilic isolate HeT36. This medium was incubated at $60^{\circ} \mathrm{C}$ for 6 days. Protein concentrations were monitored as described by Markwell et al. (1979). Protein concentrations were measured as a proxy for biomass since cell attachment to rocks made both cell counts and optical density unreliable.

\section{Identification of isolates}

Organisms were identified using 16S rDNA gene PCR amplification and sequencing. Genomic DNA was extracted from cell pellets using the FastDNA SPIN kit for soil (Qbiogene, USA) according to the manufacturer's instructions. The 16S rDNA gene was amplified using primers targeting the $\mathrm{V} 1-\mathrm{V} 9$ hypervariable regions in the following pairs pA-com2 and com1-pH (Bruce et al. 1992; Schwieger \& Tebbe 1998). This created an approximate $400 \mathrm{bp}$ overlap used to assemble the whole 16S rRNA gene. The PCR protocol was as follows: $1 \mu \mathrm{M}$ forward primer, $1 \mu \mathrm{M}$ reverse primer, $1 \mathrm{X}$ Buffer (200 mM Tris- $\mathrm{HCl}$ (pH 8.4)), 500 mM KCl (Invitrogen Corporation, Paisley, UK), $1.5 \mathrm{mM} \mathrm{MgCl}, 200 \mu \mathrm{M}$ dNTP (New England Biolabs, USA), $2.5 \mathrm{U}$ Taq (Invitrogen, Paisley, UK). The thermal cycler (G-Storm GS1 thermal cycler, GeneTechologies, Ltd, Essex, UK) protocol was as follows: 5 min $95^{\circ} \mathrm{C}, 30$ cycles of $\left(30 \mathrm{~s} 94^{\circ} \mathrm{C}, 30 \mathrm{~s} 56^{\circ} \mathrm{C}\right.$, $1 \min 72^{\circ} \mathrm{C}$ ), $3 \min 72^{\circ} \mathrm{C}$. Products were cleaned and purified (Illustra ${ }^{\mathrm{TM}} \mathrm{GFX}^{\mathrm{TM}}, \mathrm{GE}$ Healthcare, Buckinghamshire, UK). Isolates and clones were sequenced at Molecular Cloning Laboratories (MCLAB, San Francisco, USA). Clone libraries were produced using the TOPO TA Cloning kit for Sequencing (Invitrogen, Paisley, UK) according to the manufacturer's instructions.

16S rDNA gene sequences were deposited in GenBank (accession numbers JN087511-JN087517).

\section{Weathering rates of an isolate}

Although thermophiles might potentially be active, we also sought to determine whether they were capable of carrying out any active geochemical processes at the upper temperatures measured in the field site near their minimum growth temperatures. In order to assess whether thermophiles could be geochemically active, basalt dissolution rates in the presence of thermophilic isolate HeT36 were determined using Inductively Coupled Plasma Atomic Emission Spectrometry (ICP-AES) to measure the changes in elemental concentrations in the medium. To measure dissolution rates, the thermophilic isolate was inoculated into simple phosphate buffer medium, consisting of $3.2 \mathrm{mM}$ of $\mathrm{KH}_{2} \mathrm{PO}_{4}$ and $6.7 \mathrm{mM}$ of $\mathrm{K}_{2} \mathrm{HPO}_{4}$ giving a pH of 7 . Ten grams of basalt powder of particle size range 50-125 $\mu \mathrm{m}$ was added, produced using a disc mill (TEMA, Whatford Halse, UK) and a series of mesh filters that were previously autoclaved $\left(121^{\circ} \mathrm{C}\right.$ for $\left.30 \mathrm{~min}\right)$. Organics for the organisms were supplied as autochthonous organics from the rocks. Flasks were inoculated with the thermophilic isolate washed in the buffered medium. The inoculant was washed four times by centrifugation and re-suspension into MSM. The experiment was performed at $40^{\circ} \mathrm{C}$, within the range observed in the field and at $60^{\circ} \mathrm{C}$ as a control to show that the isolate could induce enhanced elemental release at conditions nearer its optimum growth temperature. The $\mathrm{pH}$ and protein concentration of the flasks were measured by removal of a $1 \mathrm{ml}$ aliquot of medium at time points throughout the experiment. Protein concentrations were measured as a proxy for biomass since cell attachment 
to rocks made both cell counts and optical density unreliable and protein concentrations were monitored as described previously. The $\mathrm{pH}$ was measured using a Hydrus 300 electronic pH meter (Fisherbrand, Leicester, UK). After 45 days of incubation, $5 \mathrm{ml}$ of media was removed and briefly centrifuged to remove suspended basalt particulates. Elemental release rates from the rocks were measured by ICPAES (Teledyne Leeman, Hudson, USA) using the methods of Wu et al. (2007) and Olsson-Francis et al. (2012). The ICP-AES data were corrected for the decrease in fluid volume and the loss of elemental mass during sampling using the following equation:

(1)

$$
C_{j, i}^{*}=\frac{C_{j, i}\left[V_{\circ}-(j-1) V_{\mathrm{s}}\right]+\sum_{h=1}^{j-1} C_{h, i} V_{\mathrm{s}}}{V_{\mathrm{o}}}
$$

$C, j, i^{*}$ is the corrected elemental concentration value of element $i$ in the $j$ sample, $C j, i$ is the original ICP-AES data, $V_{\mathrm{o}}$ is the initial fluid volume, $V_{\mathrm{s}}$ is the sample volume,

and $\sum_{h=1}^{j-1} C_{h, i} V_{s}$ accounts for the mass of element $i$ extracted during the sampling (Wu et al. 2007). The experiment was run in triplicate and sterile control experiments were run in which no inoculant was added.

\section{Results}

\section{Composition, temperature profile of Icelandic rocks and relative humidity}

The major element composition of the basalts used in this experiment is shown in Table 1. Heavy metal concentrations were 123.55, 122.64, 84.70 and 73.05 ppm for $\mathrm{Cu}, \mathrm{Cr}, \mathrm{Zn}$ and $\mathrm{Ni}$, respectively.

Table 1. Major element chemical composition of basalt used in the experiments

\begin{tabular}{llllllllll}
\hline & $\mathrm{SiO}_{2}$ & $\mathrm{TiO}_{2}$ & $\mathrm{Al}_{2} \mathrm{O}_{3}$ & $\mathrm{Fe}_{2} \mathrm{O}_{3}$ & $\mathrm{MnO}$ & $\mathrm{MgO}$ & $\mathrm{CaO}$ & $\mathrm{Na}_{2} \mathrm{O}$ & $\mathrm{K}_{2} \mathrm{O}$ \\
\hline Basalt (\% wt oxides) & 51.1 & 2.4 & 13.8 & 13.2 & 0.2 & 5.6 & 9.0 & 2.5 & 1.0 \\
\hline
\end{tabular}

aLoss on ignition.

The temperature at $2 \mathrm{~cm}$ depth within Icelandic crystalline basalt and obsidian (silica-rich glass) was logged over the period of a year (Fig. 1(a)). The annual mean temperature over that period in basalt was $4.2^{\circ} \mathrm{C}$ with a minimum of $-12.6{ }^{\circ} \mathrm{C}$. In obsidian, the values were 2.1 and $-20.1^{\circ} \mathrm{C}$, respectively. In basalt, we observed five excursions above the minimum growth temperature of the thermophile isolates examined here $\left(36^{\circ} \mathrm{C}\right)$ and one in obsidian over the year-long measurement period. By contrast, the mean air temperature above the basalt sample was $3.4^{\circ} \mathrm{C}$ with a minimum of $-11.7^{\circ} \mathrm{C}$. The air temperature during the year-long measurement period never exceeded $18.3^{\circ} \mathrm{C}$. Figure $1(\mathrm{~b})$ shows the surface temperature profile of the Icelandic obsidian for 5 days during June 2008, immediately after the year-long measurement period. The peak temperature during this time was $44.5^{\circ} \mathrm{C}$. On all 5 days of measurement, there were midday temperature excursions above the minimum growth temperature of the thermophile isolates examined here $\left(36^{\circ} \mathrm{C}\right)$. On June 12 , this excursion lasted continuously for $3 \mathrm{~h} 24 \mathrm{~min}$ and on 13 and 14 June, the excursions were intermittent over a period of $\sim 3.5 \mathrm{~h}$. 

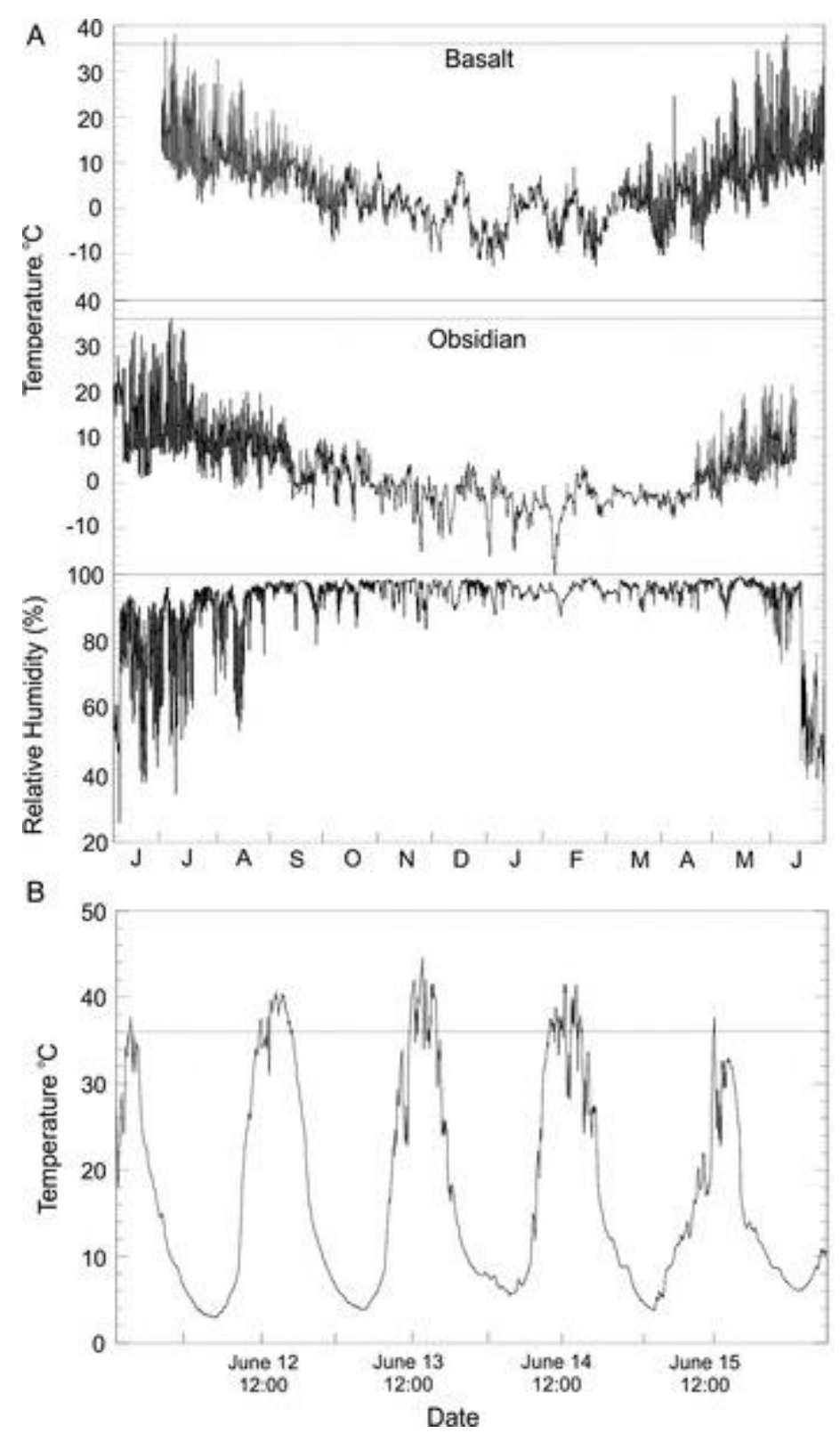

Fig. 1. Temperature profiles of Icelandic rocks and relative humidity. (a) Temperature at $2 \mathrm{~cm}$ depth for basalt [top] (4 July 2009-27 June 2010) and obsidian [middle] for 1 year (9 June 2007-11 June 2008). The horizontal dotted line show the minimum growth temperature for growth of thermophilic isolates obtained in this study. The relative humidity from 9 June 2007 to 27 June 2008 is also shown [bottom]. (b) The temperature profile of the surface of obsidian during 5 days in June (11-16) 2008.

The relative humidity at the obsidian outcrop is shown in Fig. 1(a). The mean relative humidity over the whole measurement period was $91.4 \%$. During June-August 2007, when temperatures reach their highest and there is no or very limited snow cover, the average relative humidity was $83.0 \%$.

\section{Thermophiles identified}

Seven thermophilic isolates were obtained, each sharing 16S rDNA gene sequence homology to known thermophilic Geobacillus species. The minimum and maximum growth temperatures of these organisms are shown in Table 2 . Growth below $40{ }^{\circ} \mathrm{C}$ 
was observed for isolates HeT24, Het22, HeT19, HeT36 and Het37 using the defined MSM supplemented with glucose. Growth was also observed in MSM incubations supplemented with $1 \mathrm{~g}$ of sterile basalt rock as the sole carbon source at $60^{\circ} \mathrm{C}$. This medium supported growth of isolate HeT36 for 6 days with a maximum specific growth rate of 0.128 day $^{-1}$ at $60^{\circ} \mathrm{C}$ (data not shown) demonstrating the presence of autochthonous organics capable of supporting the growth of these thermophiles.

Table 2. Thermophilic isolates. The $16 \mathrm{~S}$ rDNA GenBank identification, closest sequence match, minimum and optimum growth temperatures of thermophilic organisms isolated from Icelandic basalt rock. 'VBas' refers to isolates from Hekla basalt. 'Eyj' refers to isolate obtained from ash at the Eyjafjallajökull

\begin{tabular}{|c|c|c|c|c|c|}
\hline Intene 10. & Seypener makb & Smbing na & Eavation & Me impico & Ortimpica \\
\hline 1911) & 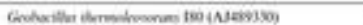 & & vant & & \\
\hline Hemonesests & 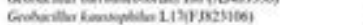 & 100 & vinet & is & is \\
\hline Iknisonatsis & 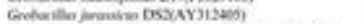 & 100 & vilant & \& & 63 \\
\hline "HeTeunasstit; & 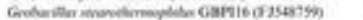 & & vant & * & $\infty$ \\
\hline Hethtanmensis? & 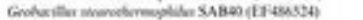 & 100 & vanat & 16 & $\omega$ \\
\hline 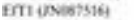 & 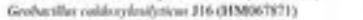 & $\%$ & En] & * & es \\
\hline mon avoonsin & 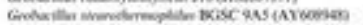 & $\boldsymbol{w}$ & viant & 40. & os \\
\hline
\end{tabular}

\section{Geochemical activity of isolate}

Rock weathering is an influential component of the global carbonate-silicate cycle (Dessert et al. 2003). Given the biogeochemical importance of this process, one parameter with which to assess the potential involvement of organisms in biogeochemistry is to examine their ability to enhance rock elemental release rates compared to an abiotic control. Flasks containing powdered basalt at $\mathrm{pH} 7$ in phosphate buffer were produced in triplicate and incubated with a thermophilic isolate. Flasks with the same conditions, but no organism (abiotic controls) were included. Although the flasks were buffered, at $60^{\circ} \mathrm{C}$ the organisms still reduced the $\mathrm{pH}$ of the medium from $\mathrm{pH} 7$ to approximately 4.8 and at $40^{\circ} \mathrm{C}$ from $\mathrm{pH} 7$ to approximately 6.1 (Fig. 2(a)). This is likely to be the result of the formation of acidic metabolic products caused by metabolism of the thermophile. Growth was confirmed by showing an increasing in the protein concentration in the flasks (concentrations of $0.47 \mathrm{mg} \mathrm{ml}^{-1}$ and $0.24 \mathrm{mg} \mathrm{ml}^{-1}$ for the 60 and $40^{\circ} \mathrm{C}$ flasks, respectively, after 45 days), as shown in Fig. 2(b). The maximum specific growth rate for the $60{ }^{\circ} \mathrm{C}$ flasks was 0.43 and 0.24 day $^{-1}$ for $40^{\circ} \mathrm{C}$ flasks. 

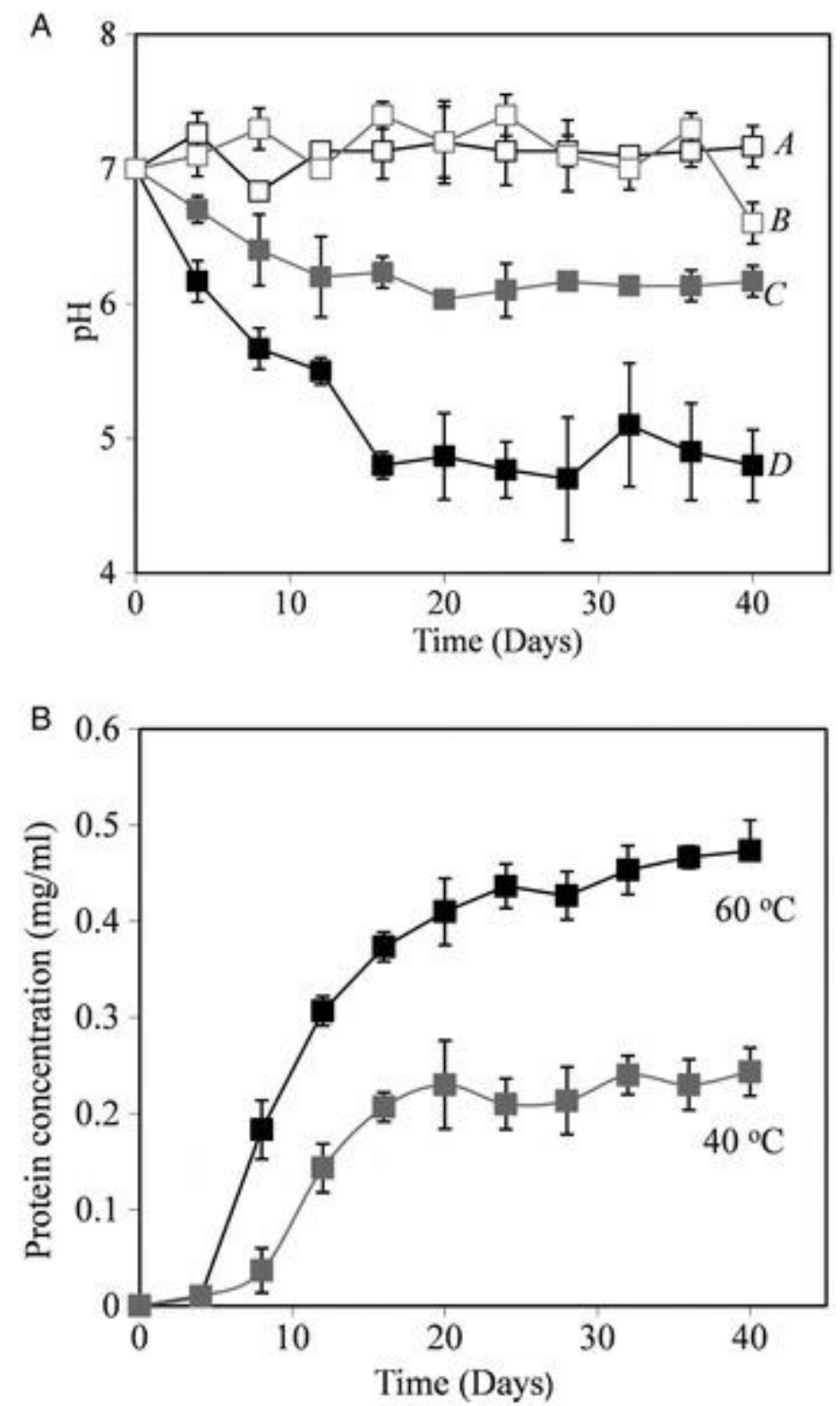

Fig. 2. Rock weathering by a thermophilic isolate. The $\mathrm{pH}$ and protein concentration in flasks. (a) pH changes. $A$, sterile control flask $40^{\circ} \mathrm{C} ; B$, flask containing a thermophilic isolate at $40^{\circ} \mathrm{C}$; $C$, sterile control flask $60^{\circ} \mathrm{C} ; D$, flask containing a thermophilic isolate at $60^{\circ} \mathrm{C}$. (b) Protein concentration of flasks containing the thermophilic isolate, no growth was observed in sterile control flasks.

Using ICP-AES, the concentration of $\mathrm{Si}, \mathrm{Ca}, \mathrm{K}, \mathrm{Mg}$ and $\mathrm{Na}$ in flasks was measured after 45 days of incubation. Element concentrations are shown in Table 3 . Element release rates in biological flasks were typically higher than in sterile flasks. Elemental release rates were found to be significantly higher $(P<0.05$, Student's $t$ test) for $\mathrm{Ca}, \mathrm{Mg}$ and $\mathrm{Si}$ in the $60^{\circ} \mathrm{C}$ flasks, and for $\mathrm{Si}$ and $\mathrm{Na}$ in the $40^{\circ} \mathrm{C}$ flasks.

Table 3. Elemental release induced by thermophilic isolates. The concentration $(\mu \mathrm{M})$ of selected elements released into solution from powdered basalt after 45 days of incubation. Biological flasks contained a thermophilic isolate, whereas control flasks remained sterile. The experiment was run in triplicate. The standard deviation of replicate flasks is given in brackets. Student's t-test was performed to determine significance differences between biological flasks and sterile controls 


\begin{tabular}{|c|c|c|c|c|}
\hline & $s$ & $\sigma$ & $w_{t}$ & $\mathrm{~N}_{4}$ \\
\hline Rodopical te0 to? & 445000 & Con 0342 & $92316 \times$ & $500202 n$ \\
\hline 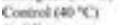 & 4 akgint) & $2004+125$ & 5700 (12.5n & misest \\
\hline S. difloresex & a.s5 & 26,7 & 41.30 & $2 \times 91$ \\
\hline Problex & an & ast & 206 & aas \\
\hline 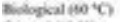 & 407601345 & $40 \times 3(2 x)$ & ruses & $\operatorname{sen} 000111.73$ \\
\hline Contend $(00)$ (c) & $2245800.3 y$ & sosus itait & 15 erch & $42 \times 3941009$ \\
\hline 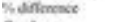 & sass & en & 5200 & 2244 \\
\hline Ponsere & $a n n$ & 0.3 & aen & ale \\
\hline
\end{tabular}

\section{Discussion}

Low air temperatures in Icelandic habitats, and indeed any cold environment on the Earth, would suggest that these are not habitats suitable for thermophiles, but instead, environments more suitable for mesophilic organisms (growth temperature optimum between 15 and $45^{\circ} \mathrm{C}$ ) or psychrophilic/tolerant organisms (optimum temperature or capacity for growth $<15^{\circ} \mathrm{C}$ ). However, we have previously observed $16 \mathrm{~S}$ rDNA sequences indicating the presence of thermophiles such as Geobacillus spp. in environmental genomic studies of Icelandic volcanic rocks and glasses (Kelly et al. 2010, 2011). Thermophiles have previously been observed in environments where conditions are generally not suitable for their propagation. For example, the spores of thermophilic sulphate reducers have been recorded in Aarhus Bay, Denmark, where water temperatures are too low to support thermophily. Their presence there is generally attributed to dispersion from hydrothermal vents and other oceanic habitats suitable for the growth of thermophiles (de Rezende et al. 2013). Thermophiles in temperate soils have previously been detected (Isaksen et al. 1994; Marchant et al. 2002, 2008; Banat et al. 2004). These organisms are thought to be deposited into these cool environments by continuous aeolian transfer (Marchant et al. 2008). For instance, Marchant et al. (2008) estimated a thermophile input rate of $1.4 \times 10^{5}$ cells $\mathrm{m}^{-2} \mathrm{yr}^{-1}$ for Irish soils and suggested this input maintains a viable population of thermophiles in this cold environment.

Similarly, one hypothesis for the presence of thermophile DNA sequences in Icelandic volcanic rocks is that they represent the DNA from thermophiles dispersed from Icelandic hot springs and other continental environments on the island where thermophiles are known to grow, or they are atmospheric contamination from outside Iceland. However, regardless of their origin, a separate question is whether any environments into which these organisms are delivered could allow for their growth.

Motivated by a desire to understand the relationship between thermophiles and the rock environment, we examined the physical environment of the rock and the physiology of the thermophiles that they contain to address the question of whether they are passive contaminants or whether they could potentially be active members of the rock community, even if only transiently.

In this study, we isolated seven thermophilic bacteria of the genus Geobacillus. Several of these organisms had a minimum growth temperature of $36{ }^{\circ} \mathrm{C}$.

Temperatures experienced in crystalline basalt and obsidian glass were examined. The former material is a common igneous material on the Earth, the latter is a silica-rich igneous material that because of its slow weathering and oxidation rate, is black coloured and therefore has low albedo. We found that on several occasions the thermal conductivity of the rocks (basalts have a conductivity typically approximately two to three orders of magnitude lower than typical metals; Robertson \& Peck 1974) was sufficient to allow for temperature excursions above $36^{\circ} \mathrm{C}$. These excursions are likely to be caused by the low albedo of the rock (McGreevy 1985). Our year-long measurements were made at $2 \mathrm{~cm}$ depth in the rocks. However, we observed surface temperatures on obsidian that exceeded $36^{\circ} \mathrm{C}$ for several hours on consecutive days in June, reaching a peak value of $44.5^{\circ} \mathrm{C}$, suggesting that in the 
near-surface environment of rocks, temperatures during the summer months offer conditions suitable for the growth of thermophiles.

These data demonstrate that although the macroclimatic temperatures are always below the temperature range classically defined for thermophily (optimum growth temperature $>45^{\circ} \mathrm{C}$ ), the microclimate within and on the rock provides an environment in which Geobacillus spp. could potentially grow.

The thermophiles identified in this study are obligate heterotrophs and thus require a source of organic carbon for growth. The organic carbon concentration of basalt glass located at $64^{\circ} 4.83^{\prime} \mathrm{N}, 19^{\circ} 32.53^{\prime} \mathrm{W}$ was approximately $0.15 \mathrm{wt} \%$ (Kelly et al. 2011). However, micro-localization and concentration of organic matter in Icelandic silicate rock pore spaces, particularly in rocks that contain phototrophs, was described by Herrera et al. (2008) and is one example of a potential source of organics for heterotrophic thermophiles. In this study, it was also observed that $1 \mathrm{~g}$ of powdered basalt in $50 \mathrm{ml}$ of defined salts media was sufficient to support the growth of thermophilic isolate HeT36, showing that autochthonous organics within the rocks can support growth of a thermophile.

We investigated the influence of active Geobacillus on the dissolution rate of basalt. In the presence of Geobacillus isolate HeT36, the average elemental release rate of the ions measured at $40{ }^{\circ} \mathrm{C}$ from powdered basalt was $25 \%$ greater when compared to sterile controls. At $60^{\circ} \mathrm{C}$ the release rate was $43.2 \%$ greater than sterile controls showing that when active, the thermophiles can also contribute to biogeochemical processes.

Geobacillus are spore-formers (Marchant et al. 2008). The germination of Bacillus spores can occur within minutes (Vary \& Halvorson 1965) and we observed high-temperature excursions lasting hours suggesting the potential for reproduction. Nevertheless, temperature excursions would be more likely to be advantageous for vegetative cells that can respond almost immediately to a short suitable growth window. Organisms also require water. The high relative humidities observed on the basalt outcrop are caused by damp Icelandic air and the frequent sustained or intermittent rain episodes experienced in this region of Southern Iceland. Although during high-temperature excursions the surface of the rock is likely to be dried from evaporation, the vesicular interiors of rocks have been observed to trap water for several days after rain events in the Arctic (Cockell et al. 2013). This suggests the possibility of high-temperature excursions occurring concomitantly with the presence of liquid water inside rocks if the period between rain and high temperatures is sufficiently short.

Our data suggest two implications for life in extreme rocky environments. First, as rock temperatures vary diurnally and seasonally, so different taxa adapted to different temperature may become active within the rock environment, suggesting the possibility of temperature-induced niche differentiation (Fig. 1). Second, if thermophiles are active in the rock environment, then warm surface rocks might represent a widespread habitat for them in addition to the more traditionally studied hot spring and caldera environments (Takacs-Vesbach et al. 2008), provided liquid water is available. This suggests a more widespread biogeography of thermophiles in continental environments, for example in rocky cold and hot deserts, than previously appreciated.

In recent decades, surface air temperatures in Arctic regions have increased at twice the rate of the global average (McBean et al. 2005). Rock temperatures increase with increasing atmospheric temperatures as observed in long-term records of air and subsurface temperatures at decimetre scales in Taiwan (Chen et al. 2011) and in records of much deeper boreholes found globally (Pollack \& Huang 2000). We might 
predict that climatic warming could increase the potential for the growth of thermophilic organisms in rock microenvironments.

These data have implications for planetary habitability. They provide a significant example of how the measurement of temperatures over regional scales on a planet or even on a whole planetary scale cannot in itself be used to predict the available niches for life. Microenvironments in rocks are known to provide protection from a number of physical extremes (McKay \& Friedmann 1985; Hall et al. 2005). The measurement or modelling of environmental conditions at the scale of microorganisms is essential for assessing the range of microbial physiologies that might be supported by such environments.

\section{Acknowledgements}

We thank the STFC for providing a studentship to PW for this work. This work was carried out in partial fulfilment of the degree of Doctor of Philosophy by PW. This work was made possible with support from the UK Science and Technology Facilities Council (STFC; Grant No. ST/1001964/1).

\section{References}

O. Arnalds (2004). Volcanic soils of Iceland. Catena 56, 3-20.

I.M. Banat , R. Marchant \& T.J. Rahman (2004). Geobacillus debilis sp. nov., a novel obligately thermophilic bacterium isolated from a cool soil environment, and reassignment of Bacillus pallidus to Geobacillus pallidus comb. nov. Int. J. Syst. Evol. Microbiol. 54, 2197-2201.

N. Barros , S. Feijóo , J. Salgado, B. Ramajo, J.R. Garcia \& L.D. Hansen (2008). The dry limit of microbial life in the Atacama Desert revealed by calorimetric approaches. Eng. Life Sci. 8, 477-486.

T.C. Beaman , H.S. Pankratz \& P. Gerhardt (1988). Heat shock affects permeability and resistance of Bacillus stearothermophilus spores. Appl. Environ. Microbiol. 54, 2515-2520.

K.D. Bruce, W.D. Hiorns , J.L. Hobman , A.M. Osborn , P. Strike \& D.A. Ritchie (1992). Ampli fication of DNA from native populations of soil bacteria by using the polymerase chain reaction. Appl. Environ. Microbiol. 58, 3413-3416.

C.-H. Chen, C.-H. Wang, D.-L. Chen, Y.-Y. Sun , J.-Y. Liu , T.-K. Yeh , H.-Y. Yen \& S.-

H. Chang (2011). Comparisons between air and subsurface temperatures in Taiwan for the past Century: a global warming perspective. In Groundwater and Subsurface Environments, ed. M. Taniguchi , pp. 185-199. Springer, Japan.

L. Claes (1968). The minimum growth temperature of obligately thermophilic bacteria as influenced by inhibitors in complex growth media. Physiol. Plantarum 21, 26-34.

C.S. Cockell , K. Olsson, F. Knowles, L. Kelly , A. Herrera, T. Thorsteinsson \& V. Marteinsson (2009). Bacteria in weathered basaltic glass, Iceland. Geomicrobiol. J. 26, 491-507.

C.S. Cockell, G.R. Osinski \& M.A. Voytek (2013). The geomicrobiology of impact structures. In Impact Cratering: Processes and Products, ed. G.R. Osinski \& E. Pierazzo , pp. 157176. Wiley, Chichester.

C.R. Cousins \& I.A. Crawford (2010). Volcano - Ice interaction as a microbial habitat on Earth and Mars. Astrobiology 11, 695-710. 
J.-L. Crovisier, T. Advocat \& J.-L. Dussossoy (2003). Nature and role of natural alteration gels formed on the surface of ancient volcanic glasses (Natural analogs of waste containment glasses). J. Nucl. Mater. 321, 91-109.

J.R. de

Rezende , K.U. Kjeldsen , C.R. Hubert , K. Finster , A. Loy \& B.B. Jørgensen (2013) Dispersal of thermophilic Desulfotomaculum endospores into Baltic Sea sediments over thousands of years. ISME J. 7, 72-84.

C. Dessert , B. Dupré , J. Gaillardet , L.M. François \& C.J. Allègre (2003). Basalt weathering laws and the impact of basalt weathering on the global carbon cycle. Chem. Geol. 202, 257-273.

M.Á. Einarsson, ed. (1984). Climate of Iceland. World Survey of Climatology: 15: Climates of the Oceans. Elsevier, Amsterdam.

K. Hall , B.S. Lindgren \& P. Jackson (2005). Rock albedo and monitoring of thermal conditions in respect of weathering: some expected and some unexpected results. Earth Surface Process. Landforms 30, 801-811.

A. Herrera, C.S. Cockell , S. Self , M. Blaxter, J. Reitner, A. Gernot, W. Drose , T. Thorsteinss on \& A.G. Tindle (2008). Bacterial colonization and weathering of terrestrial obsidian in Iceland. Geomicrobiol. J. 25, 25-37.

A. Herrera , C.S. Cockell , S. Self , M. Blaxter , J. Reitner , T. Thorsteinsson , G. Arp , W. Drose \& A. Tindle (2009). A cryptoendolithic community in volcanic glass. Astrobiology 9, 369-381.

M.F. Isaksen , F. Bak \& B.B. Jørgensen (1994). Thermophilic sulfate-reducing bacteria in cold marine sediment. FEMS Microbiol. Ecol. 14, 1-8.

L. Kelly , C.S. Cockell , Y.M. Piceno, G.L. Andersen, T. Thorsteinsson \& V. Marteinsson (2010 ). Bacterial diversity of weathered terrestrial Icelandic volcanic glasses. Microb. Ecol. 60, 740752.

L. Kelly et al. (2011). Bacterial diversity of terrestrial crystalline volcanic rocks, Iceland. Microb. Ecol. 62, 69-79.

L.A. Lawver \& R.D. Muller (1994). Iceland hotspot track. Geology 22, 311-314.

R. Marchant , I.M. Banat, T.J. Rahman \& M. Berzano (2002). The frequency and characteristics of highly thermophilic bacteria in cool soil environments. Environ. Microbiol. 4, 595-602.

R. Marchant, A. Franzetti , S.G. Pavlostathis , D.O. Tas , I. Erdbrugger , A. Unyayar , M.A. Maz manci \& I.M. Banat (2008). Thermophilic bacteria in cool temperate soils: are they metabolically active or continually added by global atmospheric transport? Appl. Microbiol.

Biotechnol. 78, 841-852.

M.K. Markwell , S.M. Haas , L.L. Bieber \& N.E. Tolbert (1979). A modification of the Lowry procedure to simplify protein determination in membrane and lipoprotein samples. Anal. Biochem. 87, 206-210.

G. McBean , G. Alekseev, D. Chen , E. Førland, J. Fyfe , P.Y. Groisman , King, H. Melling , R. Vose \& P.H. Whitfield (2005). Arctic Climate: Past and Present. Arctic Climate Impacts Assessment (ACIA). Cambridge University Press, Cambridge.

J.P. McGreevy (1985). Thermal properties as controls on rock surface temperature maxima, and possible implications for rock weathering. Earth Surface Process. Landforms 10, 125-136.

C.P. McKay \& E.I. Friedmann (1985). The cryptoendolithic microbial environment in the Antarctic cold desert: temperature variations in nature. Polar Biol. 4, 19-25. 
K. Olsson-Francis , A.E. Simpson , D. Wolff-Boenisch \& C.S. Cockell (2012). The effect of rock composition on cyanobacterial weathering of crystalline basalt and rhyolite. Geobiology 10, 434 444.

H.N. Pollack \& S. Huang (2000). Climate reconstruction from subsurface temperatures. Annu. Rev. Earth Planet. Sci. 28, 339-365.

E.C. Robertson \& D.L. Peck (1974) Thermal conductivity of vesicular basalt from Hawaii. $J$. Geophys. Res. 79, 4875-4888.

F. Schwieger \& C.C. Tebbe (1998). A new approach to utilize PCR-single-strand-conformation polymorphism for 16S rRNA gene-based microbial community analysis. Appl. Environ. Microbiol. 64, 4870-4876.

J. Striberger , S. Björck , O. Ingólfsson , K.H. Kjaer , I. Snowball \& C.B. Uvo (2010). Climate variability and glacial processes in eastern Iceland during the past 700 years based on varved lake sediments. Boreas 40, 28-45.

C. Takacs-Vesbach , K. Mitchell , O. Jackson-Weaver \& A.L. Reysenbach (2008). Volcanic calderas delineate biogeographical provinces among Yellowstone thermophiles. Environ. Microbiol. 10, 1681-1689.

J.C. Vary \& H.O. Halvorson (1965) Kinetics of germination of Bacillus spores. J. Bacteriol. 89, 1340-1347.

L. Wu , A.D. Jacobson , H.-C. Chen \& M. Hausner (2007) Characterisation of elemental release during microbe-basalt interactions at $T=28^{\circ} \mathrm{C}$. Geochim. Cosmochim. Acta 71, 2224-2239. 